\title{
Archaeology and agriculture: conflicts and solutions
}

\author{
Richard Vogt $^{1}$ and Inga Kretschmer ${ }^{2}$ \\ ${ }^{1}$ Landesamt für Denkmalpflege im Regierungspräsidium Stuttgart, Fischersteig 9, 78343 Gaienhofen- \\ Hemmenhofen, Germany \\ ${ }^{2}$ Landesamt für Denkmalpflege im Regierungspräsidium Stuttgart, Moltkestraße 74, 76133 Karlsruhe, Germany
}

Correspondence: $\quad$ Richard Vogt (richard.vogt@rps.bwl.de) and Inga Kretschmer (inga.kretschmer@ rps.bwl.de)

Relevant dates: $\quad$ Received: 16 January 2019 - Revised: 5 March 2019 - Accepted: 21 March 2019 Published: 13 June 2019

How to cite: $\quad$ Vogt, R., and Kretschmer, I.: Archaeology and agriculture: conflicts and solutions, E\&G Quaternary Sci. J., 68, 47-51, https://doi.org/10.5194/egqsj-68-47-2019, 2019.

\section{Introduction}

The archaeological soil archive that has been preserving information on human activities over thousands of years is extremely endangered by increasing land use and intensive agriculture in highly frequented regions.

Many archaeological cultural monuments are located in regions which have been settled since prehistory because of various positive location factors, such as fertile soils and sufficient water supply. In these areas modern agriculture produces high yields also today, and the arable land is therefore affected by intensive farming practices. This, in turn, puts the preservation of cultural heritage and soil archives at risk and could result in their irreversible destruction.

This paper reports common problems and approaches for problem-solving strategies that derive from daily practice and experience in cultural heritage management, as a contribution to further discussion in an international context.

The industrialization and intensification of agriculture since the 19th century has resulted in increasing losses of archaeological soil archives. Moreover, intensive soil cultivation leads to erosion in many regions, which has had a strong impact on soil conservation and on remaining archaeological structures. Land consolidation, removing boundaries of fields and terraces, has facilitated the use of large agricultural machines and enhanced erosion processes.

As a result, above-ground archaeological monuments such as tumuli fields, ramparts and ditches, which are better pre- served in grassland or in the forest, will be completely flattened and disappear in agricultural landscapes (Fig. 1). Modern ploughs dig deeply into the ground and destroy any remaining structures. Large farming machines remove or shred stones and bricks including archaeological stone structures and walls. Ploughing also leads to the removal of soil and artefacts outside of the context of archaeological features and sites. Machinery use, fertilization and usage of chemical pesticides damage finds, which is particularly evident in heavily corroded metal objects. Also drainage of moorland for peat extraction and land reclamation is a substantial danger to the preservation of wetland sites with their wooden and organic objects that can be thousands of years old (Kretschmer, 2014).

\section{Prospection and evaluation}

One method to detect erosion as well as archaeological features is the evaluation of aerial photographs. Variances in height and vegetation colour can display archaeological features like ramparts, pits or burials. However, the clearer archaeological remains are visible in aerial photographs; the closer these remains are to the surface, the more vulnerable they are to total destruction (Fig. 2). A large number of archaeological remains picked up during field prospections indicate exposure and translocation of archaeological sites.

Soil mapping by soil coring is an appropriate method for the evaluation of archaeological site conditions. The devel- 


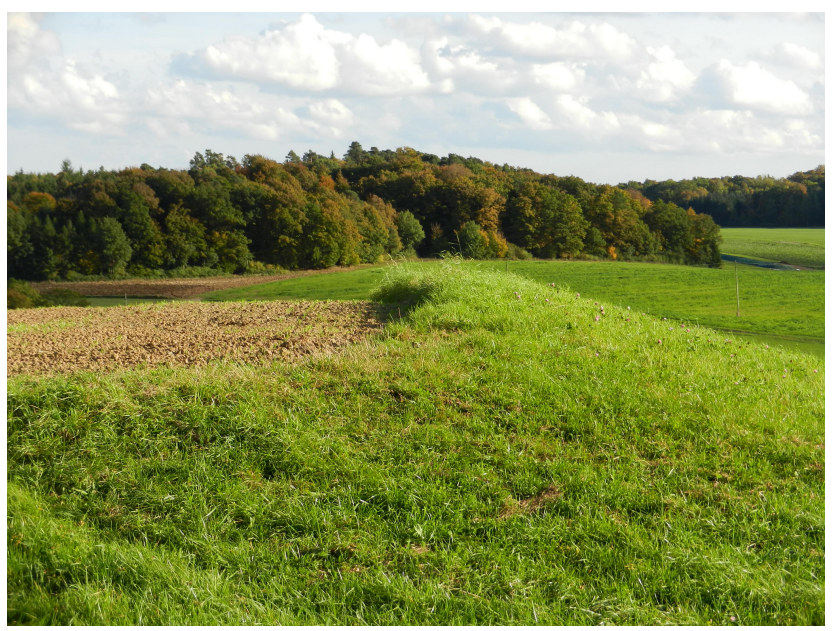

Figure 1. The rampart of the Celtic oppidum Finsterlohr (Creglingen, Baden-Württemberg) was partially flattened by ploughing (Landesamt für Denkmalpflege im Regierungspräsidium Stuttgart, LAD, Baden-Württemberg/I. Kretschmer).

opment of a soil profile helps to estimate the amounts of erosion and accumulation, especially in landscapes where Luvisols are widespread, e.g. in the German loess regions. These Luvisols are characterized by clay transfer processes from upper (elluvial) to lower (illuvial) horizons. This is very important for archaeological research questions because of their nearly constant thickness. The average thickness usually reaches around $40-50 \mathrm{~cm}$ for the elluvial and $50-70 \mathrm{~cm}$ for the illuvial horizon. Depending on the morphological situation the original soil profiles have changed due to forest clearing and the use of hills and other exposed terrain for agriculture, where erosion processes start. The large variation of current soil types in hilly areas is a result of human influence through agricultural activity over the last 6000 years. In some cases no remains of the original soil profiles were preserved, which means that more than $1 \mathrm{~m}$ of soil was lost by erosion. Eroded material will be deposited in depressions and at slope foots. A pedological survey can result in a soil map that shows the present distribution of these different kinds of soils. Assignment and depth of soil horizons and type and the determination of soil colour, content of organic material and carbonates and the moisture level are the most important parameters to be gathered by fieldwork (Behm et al., 2011). Areas of archaeological sites and their surroundings, which are strongly influenced by erosion, can be detected by soil mapping, as well as the accumulation zones, where sites are protected by a cover of colluvial deposits. Specific protection strategies can be developed in connection with land owners and the farmers by delineating erosion zones and erosion amounts.

Two case studies from the loess-covered hilly area northwest of Dresden in the surroundings of the small town Lom-

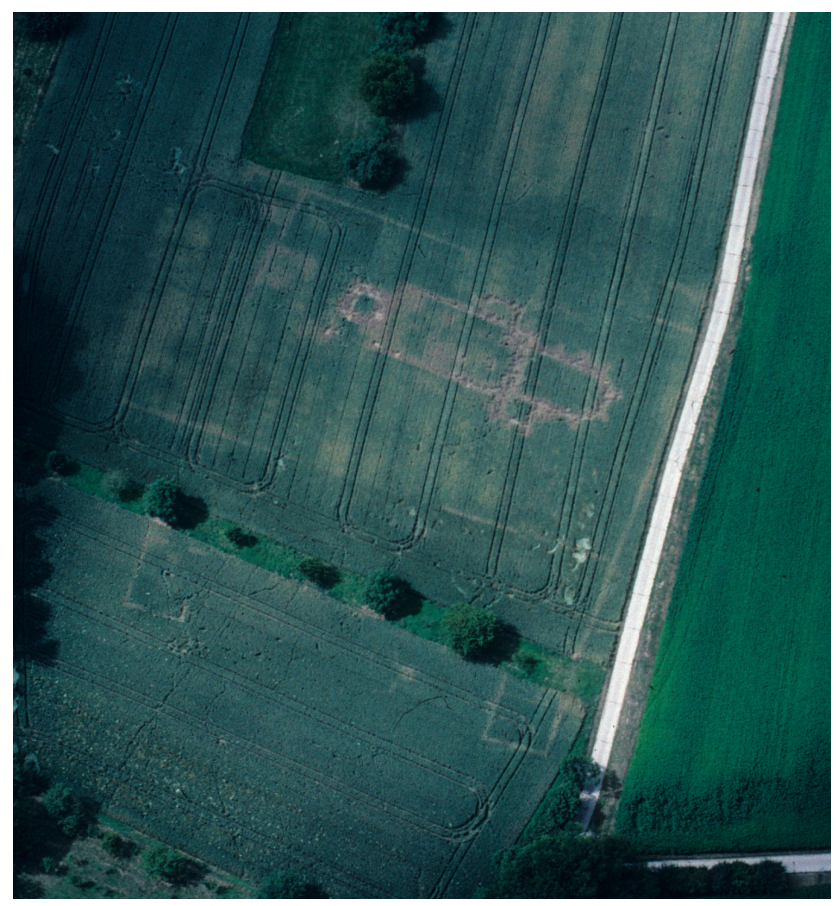

Figure 2. Aerial photograph of the remains of the Gothic church and abandoned medieval monastery in Remchingen-Wilferdingen (Baden-Württemberg) (LAD, Baden-Württemberg/O. Braasch).

matzsch in Saxony will be presented in the following to exemplify our approach and the research method.

\subsection{Case study Piskowitz-Tanzberg}

Piskowitz-Tanzberg is a large area situated on a hill and attached ridge with pits and ditches of the Linear and StrokeOrnamented Pottery Culture, as well as with burials of the late Bronze Age, early Iron Age and Roman Iron Age. The site is situated to the west of the hamlet Piskowitz. It was discovered during arable farming and was partly excavated by Johannes Deichmüller between the years 1905 and 1909. Since that time more than 100 years of agricultural land use has occurred there, and the question arose as to where it is still possible to find preserved burial remains (Behm et al., 2011).

Based on hand drillings and mapping, the analysis showed a compartmentalized mosaic of different areas of soil preservation. Promising areas with less erosion and hence potential for archaeological features could be identified. These are distributed at the nearly flat crest, where less $\left(\mathrm{Le}^{\prime}\right)$ or a little more eroded Luvisols $\left(\mathrm{Le}^{+}\right.$) occur (Fig. 3). There, east of the top, a later excavation was successful and revealed some burial remains. To the north and west, we found calcaric Regosols (pararendzinas) and calcaric Cambisols (coloured in lilac and brown) that mark areas with a nearly complete erosional loss of the original soil profiles (Ender et al., 2012). In the east, larger parts of the area were covered with collu- 
vial deposits (coloured in orange). In the north-eastern section, a small area with total profile loss can be recognized (coloured in lilac). From there to the south, a thin cover of colluvial deposits lies above brown soil. That brown soil indicates a former phase of erosion.

Soil profiles are not the only way to obtain information about the extent of erosion. The depth of the calcareous layers can also indicate it because the loess has high lime content. But calcaric components are leached and transported to lower parts of the profile during soil development. Therefore, the line of decalcification in developed Luvisols could usually be observed at a depth of about $1.20 \mathrm{~m}$ or more. In areas where profiles are shortened by erosion, the calcareous parts are closer to the surface, depending on the amount of eroded soil. In the case of pararendzinas and calcaric Cambisols, the substrate on top includes lots of calcaric components.

The evaluation of this site showed that a complete loss of the original soil profile can be observed and that the preservation at the central ridge and hilltop is rather endangered in some areas. Widespread ceramic findings in the plough horizon are also a sign for the ongoing destruction of archaeological remains. Therefore, a negative prediction for the future development needs to be given for most parts of the site. Our recommendation to protect the archaeological remains is that farmers should cultivate crops with a high degree of soil covering and implement consequent mulch tillage (Strobel et al., 2009).

\subsection{Case study Burgberg Zschaitz}

The site Burgberg Zschaitz, well known for its ramparts and ditches, is situated on a wide plateau of a hill spur and adjoins directly to the small village Zschaitz. Several remains and findings date to Middle and Late Neolithic, Late Bronze and early Iron Age. The two impressive great ramparts were constructed in Early to High Middle Ages. The rampart and ditch system separates the spur from the plateau and divides the area into an inner and outer bailey (Bromme et al., 2010). Soil mapping of the inner bailey showed that the soil profiles are completely destroyed. Only parts of the formerly very deeply buried archaeological remains are still preserved. This is due to soil erosion as a consequence of intensive agricultural land use on the one hand and man-made plantations during the Middle Ages on the other hand. Shifted soil material was deposited around the inner bailey in the north-west and south to build a rampart. The height of the main rampart in the east of the inner bailey was measured exactly during the 1950s. The comparison with a current measurement showed that during the last 60 years the rampart has levelled by about $60 \mathrm{~cm}$ due to agricultural use and ploughing (Bens et al., 2012). Moreover, the large number of archaeological findings in the plough horizon indicates rampart destruction.

The preservation state of the inner bailey and the main rampart is very poor. Fortunately it was possible to take this area out of agricultural land use and to convert it to grassland.
To obtain this result, the land had to be purchased on behalf of the preservation of sites of historic interest and nature protection. An intensive cooperation between the administration, NGOs and private landowners was necessary to realize this preservation concept.

\section{Protecting sites in farm- and wetland}

\subsection{Solutions to protect sites in farmland}

Land use such as grassland delivers the best site preservation because barely any soil erosion occurs, and no farming machines disturb deeper soil layers. Several possibilities exist to take an area with archaeological remains out of agricultural farming and ploughing, such as (i) the land purchase of archaeological cultural monument sites, (ii) the swapping of areas with field areas without archaeological remains or (iii) the financial support of pasture management. In cooperation with the departments of nature conservation, soil protection, land consolidation or road construction, archaeological sites can be used as compensation areas. Compensation measures, such as the growing of green spaces to preserve nature and landscape, are demanded when construction projects use space. Such extensification solutions are not often realisable; however it is important to test all possible options to convert farmland with archaeological sites into grassland (Kretschmer, 2016).

Another protection measure is to apply no-till methods with specific and commonly available machines. These machines reduce the risk of soil erosion by leaving plant remains on the soil surface after harvesting and covering the top. Sowing new crops can be done by mulch tillage or direct seeding without tillage. The costs for purchasing such machines could be reduced by governmental incentives.

Both pasture management and conservation soil tillage are the only measures that protect the archaeological record as a permanent solution by excluding deep ploughing after any change of agricultural management.

Invisible archaeological monuments that are at risk from ploughing could also be covered, or the terrain could be filled with additional sediments or soil material, depending on soil conservation requirements.

Last but not least, technical equipment for arable farming has developed very fast during recent years, e.g. precision agriculture with GPS and newly constructed field machines for special functional requirements. Precision farming allows the protection of archaeological sites to be managed by treating these areas differently from other parts of the same field. Shapes of archaeological monuments can be seen on computer screens on board the machine. If the tractor reaches the site the cultivator may automatically lift to continue with more shallow tillage, preventing artefacts from being pulled out of deeper layers (Kretschmer, 2014). 


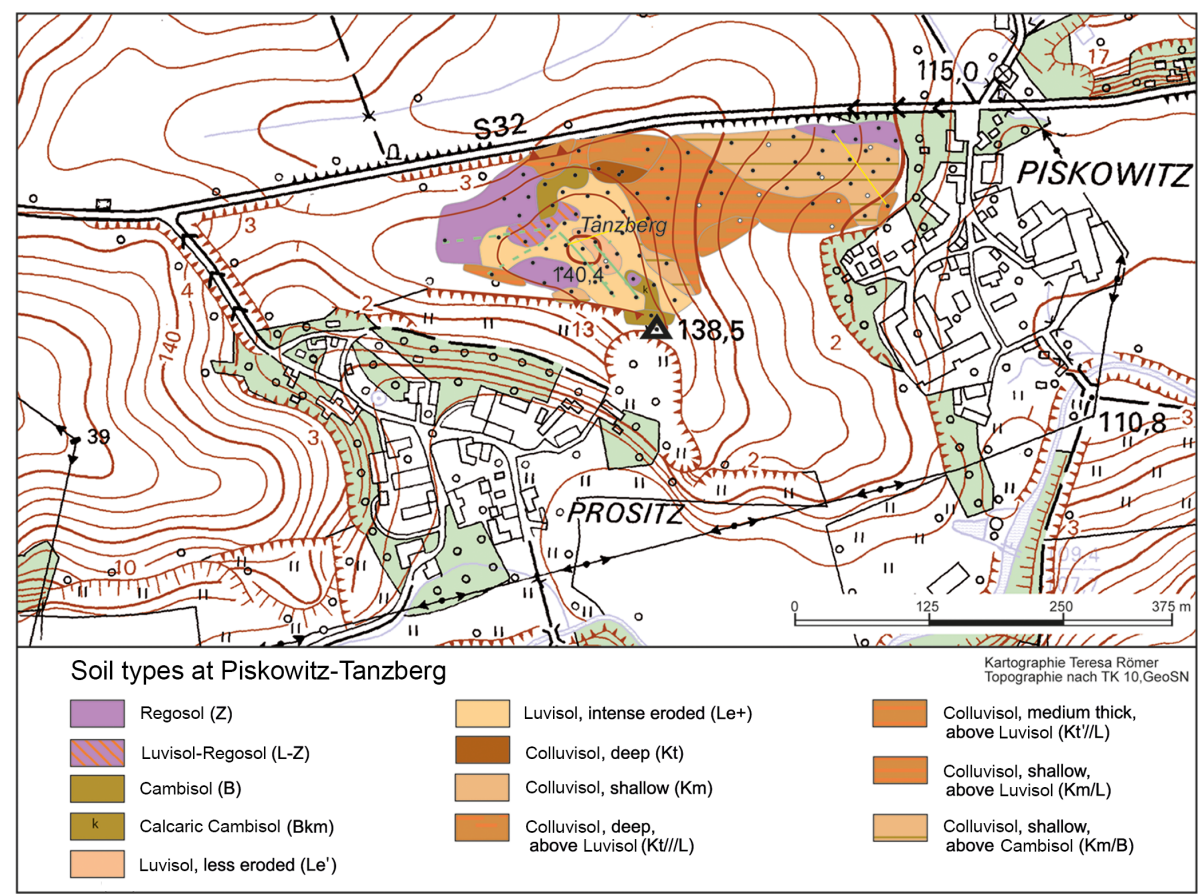

Figure 3. Detailed soil map of the surroundings of the site Piskowitz-Tanzberg (Saxony) (LfA Sachsen, T. Römer/R. Vogt).

\subsection{Endangered wetland sites}

Archaeological sites are not only threatened by agricultural use on farmland. Numerous bogs were meliorated in the past to obtain more and better grassland. Ditches or pipes were constructed to drain such areas. Descending groundwater levels resulted in humification and mineralization of peats, which often includes organic archaeological remains (Fig. 4). Thus, important information and archaeological remains could be destroyed, like famous sites of pile dwellings as well as wooden plank roads or outstanding findings like the 5000-year-old wooden disc wheels from the sites Alleshausen and Olzreute in Baden-Württemberg.

Organic material can survive thousands of years due to special preservation conditions under water and in an oxygen-free environment. The information content about pile dwellers' lives in the past and their related environment is inestimable (Aichele et al., 1999). This is why pile dwellings of six countries received UNESCO world heritage status in 2011. Most German sites are found in the south-west around Lake Constance and the Federsee region in Upper Swabia.

An area of nearly 400 ha of bog in the Federsee region was bought by the government of Baden-Württemberg to preserve archaeological cultural monuments for the future and to generate better conditions in this nature reserve. Ownership allowed the possibility to raise the groundwater level in this zone by building weirs and closing ditches. The original bog water supply could be restored, and preservation conditions of the archaeological sites were enhanced (Möllenberg and Schlichtherle, 2013).

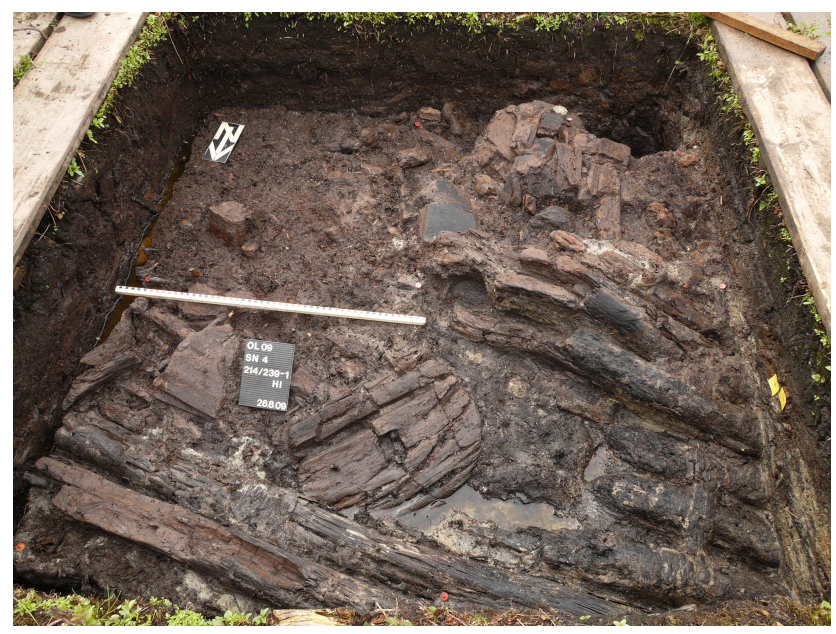

Figure 4. Wooden disc wheel in the wetland site OlzreuteEnzisholz (Baden-Württemberg) beside wooden house construction elements (LAD, Baden-Württemberg/W. Hohl).

Yet, bog melioration remains a problem in other places. The Bodnegg site in the Allgäu region, discovered in 2014, serves as a good example. A fireplace with stony and loamy material was excavated beneath the dry soil surface. Settlement structures on this site were built on peat around 3900 BCE. This peat today has been totally transformed by the influence of oxygen in its upper parts because of the lower groundwater level. Thus, wooden parts of the houses and non-carbonized organic remains of the cultural layers have 
only survived in the lower parts (Ebersbach et al., 2017). Special protection strategies for such places need to be developed in every region.

\section{Conclusions}

The preservation of archaeological sites is endangered by many different effects of agricultural use, such as the deep ploughing of soils during cultivation, soil migration by machines, soil erosion by rainfall, drying wetlands by decreasing water levels or by the use of pesticides and fertilizers.

It can be shown that every site is different from another and inhomogeneous in itself. Therefore, an individual evaluation and development of solutions is needed for every single archaeological site. A joint concept for solutions and for protection strategies is necessary, incorporating the interests of landowners and farmers (Strobel et al., 2009). To obtain good results, many stakeholders from different departments need to be involved: agriculture, forestry, heritage management, nature conservation, sustainable soil protection and land consolidation (for more information, see, for example, https://www.denkmalpflege-bw. de/fileadmin/media/denkmalpflege-bw/publikationen/ infobroschueren/informationen-praktische-denkmalpflege/ 10_archaeologie-landwirtschaft-forstwirtschaft/ Broschuere_Archaeologie-Landwirtschaft-Forstwirtschaft. pdf (last access: 14 December 2018).

Every single method helps to preserve the archaeological heritage, yet maximum protection is usually not achievable.

Data availability. All raw data of the drillings are stored at the Landesamt für Denkmalpflege im Regierungspräsidium Stuttgart (Richard Vogt) and can be obtained upon reasonable request.

Author contributions. RV carried out the fieldwork (drillings, observations and descriptions). The manuscript was written by IK and RV.

Competing interests. The authors declare that they have no conflict of interest.

Special issue statement. This article is part of the special issues "Geoarchaeology and past human-environment interactions".

Acknowledgements. A part of the research was done during the model study in Saxony "Archäologie und Landwirtschaft", funded by the Deutsche Bundesstiftung Umwelt (DBU). Thanks are expressed to Thomas Westphalen and Michael Strobel for project management.

\section{References}

Aichele, G., Banghard, K., Billamboz, A., Einstein, J., Maier, U., Schlichtherle, H., Schwab, S., Strobel, M., and Wernicke, K.: Archäologie und Naturschutz im Federseemoor, Landesdenkmalamt Baden-Württemberg, Stuttgart, 47 pp., 1999.

Behm, H., Bräunig, A., Ende, F., Hartsch, K., Schmidt, W.-A., Schob, A., Strobel, M., Ueberfuhr, F., Vogt, R., Voss, J., and Westphalen, T.: Archäologie und Landwirtschaft, Wege zu einem partnerschaftlichen Verhältnis in Hochertragslandschaften, Erfahrungen aus einem Modellprojekt in der Lommatzscher Pflege (Freistaat Sachsen), Deutsche Bundesstiftung Umwelt, Sächsisches Landesamt für Archäologie, Sächsisches Landesamt für Umwelt, Landwirtschaft und Geologie, Verband der Landesarchäologen in der Bundesrepublik Deutschland e.V., Osnabrïck, 87 pp., 2011.

Bens, S., Olkusznik, A., Schulze, H., Strobel, M., Ullrich, B., Vogt, R., Voss, J., Weißenbern, P., and Westphalen, T.: Zukunft für ein bedeutendes archäologisches Kulturdenkmal - der Burgberg Zschaitz, Ausgrabungen in Sachsen 3, 92-100, Dresden, 2012.

Bromme, V., Ende, F., Hardtke, H.-J., Kinne, A., Slobodda, S., Strobel, M., Ullrich, B., Vogt, R., Westphalen, T., and Winkler, C.: Der Burgberg Zschaitz in der Lommatzscher Pflege - Landschaft, Natur und Archäologie, Archaeonaut 9, Dresden, 24 pp., 2010.

Ebersbach, R., Kleinmann, A., Maier, U., Mainberger, M., Merkt, J., Million, S., Nelle, O., Schlichtherle, H., Stephan, E., Vogt, R., and Wick, L.: Das BELAVI-Projekt erschließt eine neue Fundlandschaft des Neolithikums im Westallgäu, Archäologische Ausgrabungen in Baden-Württemberg 2016, Darmstadt, 22 25, 2017.

Ender, W., Kinne, A., Strobel, M., and Vogt, R.: Das Gräberfeld auf dem Tanzberg bei Piskowitz/Prositz (Stadt Lommatzsch, Kr. Meißen) - eine archäologisch-bodenkundliche Nachlese, Ausgrabungen in Sachsen 3, Dresden, 75-81, 2012.

Kretschmer, I.: Archäologie - Landwirtschaft - Forstwirtschaft, Ein Projekt zur integrativen Nutzung von Bodendenkmalen in der Kulturlandschaft, Archäologische Ausgrabungen in BadenWürttemberg 2013, Darmstadt, 20-23, 2014.

Kretschmer, I.: Zum Fortgang des Projekts Archäologie - Landwirtschaft - Forstwirtschaft, Schutz und Erhalt von Bodendenkmalen in land- und forstwirtschaftlichen Nutzungsgebieten, Archäologische Ausgrabungen in Baden-Württemberg 2015, Darmstadt, 22-25, 2016.

Möllenberg, S. and Schlichtherle, H.: Archäologische Denkmale, Bodenerosion und Mineralisierung, Über das leise Verschwinden von Bodendenkmalen, Denkmalpflege in Baden-Württemberg 1/2013, Stuttgart, 9-14, 2013.

Strobel, M., Vogt, R., and Westphalen, T.: Die Lommatzscher Pflege - eine sächsische Altsiedellandschaft, Mitteilungen Landesverein Sächsischer Heimatschutz 2/2009, Mügeln, 4-12, 2009. 